\title{
Effects of different algal diets and carbon supplies on larval development, growth and survival in the freshwater copepod Mongolodiaptomus malaindosinensis (Copepoda: Calanoida)
}

\author{
Phuttaphannee Boonmak ${ }^{1}$, Xin LiU $^{2}$, Syuhei Ban ${ }^{2} \&$ La-Orsri Sanoamuang ${ }^{1,3} *$ \\ ${ }^{1}$ Applied Taxonomic Research Center, Department of Biology, Faculty of Science, Khon Kaen University, Khon Kaen 40002, \\ Thailand \\ ${ }^{2}$ School of Environmental Science, The University of Shiga Prefecture, 2500 Hassaka-cho, Hikone, Shiga 5228533, Japan \\ ${ }^{3}$ International College, Khon Kaen University, Khon Kaen 40002, Thailand
}

Received 8 April 2018; Accepted 22 August 2018 Responsible Editor: Toru Kobari

doi: $10.3800 /$ pbr. 13.163

\begin{abstract}
The freshwater calanoid copepod Mongolodiaptomus malaindosinensis is an endemic species of the lower Mekong basin, including Malaysia. The relationships between environmental factors and life history traits have been reported for many copepods, while they have never been assessed in this tropical species. Post-embryonic development time (post-EDT), body size and survival rate of M. malaindosinensis were determined under different algal concentrations of Chlamydomonas reinhardtii and Cryptomonas tetrapyrenoidosa at $25^{\circ} \mathrm{C}$, to clarify the effects of algal species and carbon supply on their somatic growth and survival. Post-EDT until adult in M. malaindosinensis decreased with increasing food carbon supply regardless of the algal species tested. Although naupliar developments were the shortest at $10^{4}$ cells $\mathrm{mL}^{-1}$ of $C$. reinhardtii, food shortage delayed the development time and also induced high mortality during the copepodid stages. The highest survival rate of $93 \%$ was obtained in the copepods fed on C. tetrapyrenoidosa at $5 \times 10^{4}$ cells $\mathrm{mL}^{-1}$, whereas the survival rates in the remaining lower carbon supply were $<23 \%$. The most sensitive stages were the 1 st copepodid stage, as indicated by high stage-specific mortalities, because of large morphological and physiological changes in this transitional stage. Prosome length of adult $M$. malaindosinensis positively correlated with food carbon supplies, though females were larger than males. Somatic growth rate exponentially increased with increasing food carbon supplies with a threshold at around $4.0 \mathrm{mgC} \mathrm{L}^{-1}$. These results suggest that tropical copepods may be adapted to higher food quantities due to their high metabolic rates under high temperature conditions.
\end{abstract}

Key words: Chlamydomonas reinhardtii, Cryptomonas tetrapyrenoidosa, post-embryonic development, tropical copepod, zooplankton

\section{Introduction}

Copepods are the most diverse and widely distributed multicellular organisms in both marine and freshwater ecosystems. They play a crucial role in the food chain for linking to higher trophic levels (Williamson \& Reid 2001). Apart from being a component of the aquatic ecosystem, copepods are particularly rich in essential unsaturated fatty acids (Piasecki et al. 2004) and can also be an important

*Corresponding author: La-orsri Sanoamuang; E-mail, la_orsri@kku. ac.th food resource for the local people living in Southeast Asia (Kottelat 2007).

Both temperature and food conditions have been shown to affect life history traits of copepods (Ban 1994, Hansen \& Santer 1995, Liu et al. 2015). Copepods are therefore sensitive to environmental changes (Mauchline 1998, Almeida et al. 2012). Previous studies have shown that the life history traits of copepods exhibited more sensitive responses to food conditions than temperature (Ban 1994, Liu et al. 2015). Anthropogenic impacts such as global warming and eutrophication induced complex changes in plankton communities through nutritional and thermal 
changes in the environments (Hsieh et al. 2010, 2011). It is therefore important to determine how copepods respond to variable food conditions.

Food conditions for zooplankton cause major changes in their species composition and population structure. For example, Wu (1999) showed that a copepod community was replaced by small-sized, gelatinous zooplankton after eutrophication. Successful development of copepods in larval stages may depend on food requirements (Hansen \& Santer 1995). Although both food quantity (i.e. carbon supply) and food quality (i.e. algal species) have been shown to affect life history traits in many temperate copepods (Ban 1994, Twombly \& Burns 1996, Dahl et al. 2009, Liu et al. 2015). It is known that nutritionally poor foods, such as cyanobacteria and diatoms, cause decreased growth rates and reduced body sizes in copepods (Hart \& Santer 1994, Hart 1996, Burns 1998, Dahl et al. 2009). A poor-quality diet can also prolong the duration of each developmental stage (Peterson et al. 1991, McKinnon 1996).

Algal species-specific nutritional components might affect the success of copepod populations (Koski \& Breteler 2003, Santhanam et al. 2015). Previous studies in temperate copepods have shown that a carbon supply of $1 \mathrm{mgC} \mathrm{L}^{-1}$ of Chlamydomonas reinhardtii Dangeard, 1888 and Cyclotella meneghiniana Kutzing, 1844 were sufficient for naupliar development but were inferior or inadequate for copepodid development (Hart \& Santer 1994), and that Cryptomonas erosa Ehrenberg, 1832 is a higher quality food for copepod growth than $C$. reinhardtii, i.e. the survival rate of two species of Diaptomus minutus Lilleborg, 1889 and Epischura lacustris Forbes, 1882 showed higher survival rates when they were fed with C. erosa (ca. 50-80\%) than with the C. reinhardtii $(<35 \%)$ (Celia \& Folt 1993).

In Thailand, over 1,600 millimeters of annual rainfall is commonly recorded (Royal Irrigation Department 2016), and more than 11,000 freshwater ponds, rivers and/or small reservoirs can be found (Sanoamuang 2002). These freshwater habitats can have high biodiversity, including copepods, with ca. 10 species of calanoids being recorded from a single habitat in the northeast of Thailand (Sanoamuang 1999). In general, temperature raises metabolic costs in aquatic organisms (Brown et al. 2004, Liu \& Ban 2017) and water temperatures can always be $>25^{\circ} \mathrm{C}$ during the year in tropical regions (Tordesillas et al. 2016). Planktonic copepods in tropical regions might exhibit higher energy demand with higher metabolic costs compared to those in temperate areas (Beyrend-Dur 2010). The effects of environmental factors on the life history traits of tropical freshwater copepods are still rarely and only sporadically reported. Recent studies on the tropical calanoid Arctodiaptomus dorsalis Marsh, 1907 collected from Lake Taal (Philippines) showed that this copepod can grow to be an adult within one month, with varying survival rates of $23-67 \%$ when reared with the single algal source of Chlamydomonas reinhardtii (Tordesillas et al. 2016), how- ever, the highest egg production rate was obtained under a cell concentration of $2 \times 10^{5} \mathrm{~mL}^{-1}$ at $30^{\circ} \mathrm{C}$ (Tordesillas et al. 2018). Since food selectivity in copepods is strongly influenced by both particle quality and the abundance of alternative foods (DeMott 1986, 1989, Kiørboe 2016), the widespread distribution of copepods in tropical waters might be due to their wider utilization of available food sources in the field.

Previous studies on freshwater copepods in Thailand have mainly focused on taxonomy, diversity and distribution (i.e. Ranga Reddy et al. 1997, 2000, Sanoamuang 1999, 2001, 2004, Sanoamuang \& Teeramaethee 2006, Proongkiat \& Sanoamuang 2008, Watiroyram \& Sanoamuang 2017). The tropical freshwater calanoid copepod Mongolodiaptomus malaindosinensis (Lai \& Fernando, 1978), which is an endemic species in the lower Mekong basin, can be commonly found in many lakes and ponds in Thailand, Laos, Cambodia, Vietnam (Sanoamuang 2002), and Malaysia (Lai \& Fernando 1978). The life history traits of this copepod, however, have never been studied before. In this study, we firstly cultured this copepod by supplying different algal diets in the laboratory, determined post-embryonic development, larval growth and assessed survival under different carbon supplies of two algal diets, in order to clarify how this tropical copepod responds to different food supplies of two different algae.

\section{Materials and Methods}

\section{Field collection and stock cultures}

Zooplankton samples were collected with horizontal hauls using a conical plankton net (mesh size: $60 \mu \mathrm{m}$, diameter: $30 \mathrm{~cm}$ ) in the littoral zone (depth: $2 \mathrm{~m}$ ) of a pond located in the north of Kaeng Nam Ton $\left(16^{\circ} 24^{\prime} 29.97^{\prime \prime} \mathrm{N}\right.$, $102^{\circ} 45^{\prime} 39.08^{\prime \prime} \mathrm{E}$ ), in the province of Khon Kaen, Thailand, on 25 September 2015. Then, ovigerous females of Mongolodiaptomus malaindosinensis were sorted from the zooplankton samples under a stereo microscope (Olympus, SZ-PT) at a magnification of ca. $40 \times$, using the taxonomic keys and descriptions of Sanoamuang (2002).

In this study, the culturing procedures for copepods were almost the same as those described in Liu et al. (2015). Copepods sorted from the field sample were cultivated in 1-L jars filled with filtered (Whatman GF/F, diameter: $47 \mathrm{~mm}$ ), autoclaved and well-oxygenated tap water (FTW) as stock cultures. The stock cultures were maintained at $25^{\circ} \mathrm{C}$ under a photoperiod of $12 \mathrm{~L}: 12 \mathrm{D}$ with a light intensity of ca. $20 \mu \mathrm{mol} \mathrm{m}^{-2} \mathrm{~s}^{-1}$ in an incubator (Sanyo, MLR-350). Copepods were fed with ca. $5 \times 10^{4}$ cells $\mathrm{mL}^{-1}$ on $1: 1$ (cells : cells) fresh algal mixture of Chlamydomonas reinhardtii (IAM C-9) and Cryptomonas tetrapyrenoidosa (NIES 282), which have been previously used in many life history studies (e.g. Celia \& Folt 1993, Liu et al. 2015, Tordesillas et al. 2018). The former is small size (ca. $5 \mu \mathrm{m}$ ) with a low carbon content per cell, while 
Table 1. Cell diameters $(\mu \mathrm{m})$ and carbon contents $\left(\mathrm{pgC}\right.$ cell $\left.{ }^{-1}\right)$ in two algae, Chlamydomonas reinhardtii and Cryptomonas tetrapyrenoidosa, and carbon concentrations $\left(\mathrm{mgC} \mathrm{L}^{-1}\right)$ for each of the six food conditions.

\begin{tabular}{|c|c|c|c|c|c|c|}
\hline \multirow{2}{*}{ Algal species } & \multirow{2}{*}{$\begin{array}{l}\text { Cell diameter } \\
\qquad(\mu \mathrm{m})\end{array}$} & \multirow{2}{*}{$\begin{array}{l}\text { Carbon content } \\
\left(\mathrm{pgC} \mathrm{cell}^{-1}\right)\end{array}$} & \multicolumn{4}{|c|}{ Carbon concentration $\left(\mathrm{mgC} \mathrm{L}^{-1}\right)$} \\
\hline & & & $10^{3}$ cells $\mathrm{mL}^{-1}$ & $10^{4}$ cells $\mathrm{mL}^{-1}$ & $5 \times 10^{4}$ cells $\mathrm{mL}^{-1}$ & $10^{5}$ cells $\mathrm{mL}^{-1}$ \\
\hline C. reinhardtii & 5 & 40.9 & 0.04 & 0.41 & 2.05 & 4.09 \\
\hline C. tetrapyrenoidosa & $10-15$ & 473.6 & 0.47 & - & 23.68 & - \\
\hline
\end{tabular}

the latter is larger $(10-15 \mu \mathrm{m})$ with a higher carbon content (Table 1). The culture medium was changed weekly and fresh food suspensions were provided every 2 days. Algal cultures were grown in a 1-L flask at $20^{\circ} \mathrm{C}$ under a photoperiod of $12 \mathrm{~L}: 12 \mathrm{D}$ with a light intensity of ca. $130 \mu \mathrm{mol} \mathrm{m}^{-2} \mathrm{~s}^{-1}$ in an incubator (Sanyo, MLR-350).

\section{Experimental conditions}

Water temperatures ranged $25-30^{\circ} \mathrm{C}$ in the original habitat (pond) throughout the year (authors' unpublished data). Thus, prior to the experiments, copepods were acclimatized at $25^{\circ} \mathrm{C}$ for at least one generation under the same food conditions as the stock culture. After acclimatization, copepods were individually reared under four food concentrations (i.e. $10^{3}, 10^{4}, 5 \times 10^{4}$ and $10^{5}$ cells $\mathrm{mL}^{-1}$ ) of Chlamydomonas reinhardtii, or two food concentrations $\left(10^{3}\right.$ and $5 \times 10^{4}$ cells $\left.\mathrm{mL}^{-1}\right)$ of Cryptomonas tetrapyrenoidosa. Those food concentrations, which covered large ranges of carbon supply, are necessary for development in copepods (e.g. Liu et al. 2015, Tordesillas et al. 2018), and allowed for evaluation of the effects of food supply on this copepod both quantitatively and qualitatively. Carbon contents under each of the different food conditions were summarized in Table 1. All experiments were conducted under the same light and temperature conditions as those in the stock culture.

\section{Experiments on post-embryonic development}

Ovigerous females were isolated from the stock cultures and individually transferred to each $10-\mathrm{mL}$ well of a 6 -well polystyrene tissue-culture plate (Trueline, TR5000) filled with FTW, and placed in an incubator (Sanyo, MLR-350) at $25^{\circ} \mathrm{C}$. Nauplii hatched within 12 hours from the eggs carried by the females, were sorted, and individually placed into wells in the tissue-culture plates filled with algal food suspension. A total of 204 newly hatched nauplii (N1) from more than five females were used in this study. The experimental animals were transferred every day to new, clean tissue-culture plates filled with fresh algal food suspension. All developmental stages, i.e. six naupliar (N1-N6) and six copepodid stages ( $\mathrm{C} 1-\mathrm{C} 5$ and adult), were observed. Exuviae or dead animals were checked four times per day (every six hours) under a dissecting microscope (Olympus, SZX12) at a magnification of ca. $10-20 \times$ to determine the development time and survival rate. Time zero was defined as the time when the $\mathrm{N} 1$ hatched from the egg. Stage duration $i$ represents the inter-molt duration calculated from the age of molting from the developmental stage $i$ to $i+1$ for each individual. Sex can be distinguished after $\mathrm{C} 5$, and sex ratios (female/male) were also calculated after the sex of all adults were confirmed at the end of each experiment.

\section{Body size measurement}

Prosome lengths $(P L)$ of copepodid stages were measured using the exuviae under a dissecting microscope (Olympus, SZX12) at a magnification of $90 \times$ with an eyepiece micrometer attached to the microscope (accuracy to $11.1 \mu \mathrm{m}) . P L$ was measured as the length from the tip of the head to the posterior margins of the last thoracic segment in exuviae. $P L$ of each adult was measured after the experimental animal died and was preserved with neutral $5 \%$ sugar formalin.

\section{Somatic growth}

Somatic growth rates were estimated using a method similar to that of Liu et al. (2014) for another freshwater copepod. Adults were not included in the estimation due to only a few individuals moulting to adult in food-limited treatments (e.g. $5 \times 10^{4}$ and $10^{5}$ cells $\mathrm{mL}^{-1}$ of C. reinhardtii). The body dry-weight $(W, \mu \mathrm{g})$ was calculated from the $P L(\mu \mathrm{m})$ using the length-weight equation for tropical calanoid copepods defined by Chisholm \& Roff (1990):

$$
\ln W=2.74 \ln P L-16.41 \text {. }
$$

The calculated body dry-weights were then used to estimate the growth rates of $M$. malaindosinensis at each food carbon concentration $\left(F C, \mathrm{mg} \mathrm{L}^{-1}\right)$. The log-transformed body dry-weight for each stage was linearly plotted against cumulative development time ( $D T$, days). The slope is the instantaneous growth rate $\left(g\right.$, day $\left.^{-1}\right)$ under each food condition. The $g$ was fitted to an exponential function of logtransformed $F C$ to clarify the relationship between $g$ and $F C$.

\section{Data analyses}

In order to evaluate the effects of carbon supply on development, body size and survival in Mongolodiaptomus malaindosinensis, food concentrations for each algal diet were transformed to carbon weight due to the different sizes of Chlamydomonas reinhardtii and Cryptomonas tetrapyrenoidosa (Table 1). To determine the carbon contents of the two algal species, algal suspensions with cell numbers of ca. $1.31 \times 10^{5}-1.03 \times 10^{8}$ were filtered using pre-combust- 
ed $\left(450^{\circ} \mathrm{C}\right.$, five hours) glass fiber filters (Whatman, GF/F), then the carbon content of filtered algal cells was measured using a CHN analyzer (Yanako, MT-5). The resulting carbon weights of $C$. reinhardtii and $C$. tetrapyrenoidosa were 40.9 and $473.6 \mathrm{pgC} \mathrm{cell}^{-1}$, respectively (Table 1 ). In order to clarify the relationship between somatic growth and carbon supply, regression analyses were made between post-embryonic development time (post-EDT, days) until adulthood or $P L(\mathrm{~mm})$ of adult and natural log-transformed carbon concentration of algal foods $\left(F C, \mathrm{mgC} \mathrm{L}^{-1}\right)$. The differences between male and female on post-EDT and $P L$ were tested by analysis of covariance (ANCOVA).

Kruskal-Wallis tests were performed to evaluate the differences in stage duration of nauplii (from N1 to N6) and copepodites (from $\mathrm{C} 1$ to Adult) and pooled stage-specific survival rates of C1-4 between different food conditions, and then the post hoc Tukey-Kramer test was conducted when the Kruskal-Wallis test resulted in a significant difference. Stage duration of copepodites at $5 \times 10^{4}$ and $10^{5}$ cells $\mathrm{mL}^{-1}$ of $C$. reinhardtii and a stage specific survival rate at $5 \times 10^{4}$ cells $\mathrm{mL}^{-1}$ for $C$. reinhardtii were not included in the analysis due to insufficient data points. The differences in the post-EDT until adult and the adult $P L$ between the copepods reared with the two algal diets at $10^{4}$ cells $\mathrm{mL}^{-1}$ of $C$. reinhardtii and $10^{3}$ cells $\mathrm{mL}^{-1}$ of $C$. tetrapyrenoidosa were tested by analysis of vari- ance (ANOVA) due to having almost the same carbon concentration (see Table 1). All statistical analyses were performed with SPSS 19.0 software (IBM Inc 2011) and MATLAB software (The MathWorks Inc 2009). The significance level was set as $p<0.05$.

\section{Results}

\section{Post-embryonic development}

Results of post-embryonic development in Mongolodiaptomus malaindosinensis at different food conditions are summarized in Table 2. According to microscopic observations, empty guts and many lipid droplets were found inside the bodies of the 1st naupliar stage (N1). The shortest mean stage duration $(D)$ was mainly observed in N1, i.e. 0.83 days, compared with those of other stages, except for that of $\mathrm{N} 2$ at the highest concentration of Cryptomonas tetrapyrenoidosa, which was 0.77 days. During naupliar stages, $D$ of each stage was around one day, whereas copepodites required a longer time than nauplii did to develop, especially at the lowest algal concentration of $10^{3}$ cells $\mathrm{mL}^{-1}$ of Chlamydomonas reinhardtii.

In Chlamydomonas reinhardtii diets, mean post-EDT until adult male was 34.8 and 18.7 days at $10^{3}$ and $10^{4}$ cells $\mathrm{mL}^{-1}$, respectively, whereas no males grew up to the adult

Table 2. Mean stage durations (D, days) with standard deviation (s.d.), and stage specific survival rates (\%) of the copepod Mongolodiaptomus malaindosinensis from a tropical pond reared with Chlamydomonas reinhardtii (Chl.) at $10^{3}, 10^{4}, 5 \times 10^{4}$ and $10^{5}$ cells $\mathrm{mL}^{-1}$, and Cryptomonas tetrapyrenoidosa (Cry.) at $10^{3}$ and $5 \times 10^{4}$ cells $\mathrm{mL}^{-1}$ at $25^{\circ} \mathrm{C}$. Sex ratios (female/male) and the survival rates of the adult stage are also indicated. N1-N6, naupliar stages; C1-C5, copepodite stages; M, male; F, female; n, number of individuals in each stage; N1-adult, post-embryonic development time from hatching to adulthood. “-” denotes no data due to few or no survivors. Stage duration was separately calculated for males and females from C5.

\begin{tabular}{|c|c|c|c|c|c|c|c|c|c|c|c|c|c|c|c|c|c|c|c|c|c|c|c|}
\hline \multirow{2}{*}{ Stage and sex } & \multicolumn{4}{|c|}{$\begin{array}{l}\text { Chl. } 10^{3} \\
\text { cells } \mathrm{mL}^{-1}\end{array}$} & \multicolumn{4}{|c|}{$\begin{array}{c}\text { Chl. } 10^{4} \\
\text { cells } \mathrm{mL}^{-1}\end{array}$} & \multicolumn{4}{|c|}{$\begin{array}{l}\text { Chl. } 5 \times 10^{4} \\
\text { cells } \mathrm{mL}^{-1}\end{array}$} & \multicolumn{4}{|c|}{$\begin{array}{l}\text { Chl. } 10^{5} \\
\text { cells } \mathrm{mL}^{-1}\end{array}$} & \multicolumn{4}{|c|}{$\begin{array}{c}\text { Cry. } 10^{3} \\
\text { cells } \mathrm{mL}^{-1}\end{array}$} & \multicolumn{3}{|c|}{$\begin{array}{l}\text { Cry. } 5 \times 10^{4} \\
\text { cells } \mathrm{mL}^{-1}\end{array}$} \\
\hline & $D$ & s.d. & $\%$ & $n$ & $D$ & s.d. & $\%$ & $n$ & $D$ & s.d. & $\%$ & $n$ & $D$ & s.d. & $\%$ & $n$ & $D$ & s.d. & $\%$ & $n$ & $D$ & s.d. & $n$ \\
\hline No. of eggs & & & & 48 & & & & 36 & & & & 30 & & & & 30 & & & & 30 & & & 30 \\
\hline N1 & 0.93 & 0.19 & 100 & 48 & 0.61 & 0.33 & 97 & 35 & 0.78 & 0.19 & 100 & 30 & 0.71 & 0.39 & 90 & 27 & 0.95 & 0.34 & 100 & 30 & 0.98 & 0.25100 & 30 \\
\hline N2 & 0.95 & 0.15 & 100 & 48 & 0.80 & 0.30 & 97 & 34 & 1.04 & 0.00 & 100 & 30 & 0.91 & 0.17 & 93 & 25 & 1.02 & 0.42 & 100 & 30 & 0.77 & 0.13100 & 30 \\
\hline N3 & 1.03 & 0.13 & 100 & 48 & 0.81 & 0.15 & 100 & 34 & 1.00 & 0.00 & 100 & 30 & 0.96 & 0.20 & 100 & 25 & 1.41 & 0.43 & 100 & 30 & 1.00 & 0.14100 & 30 \\
\hline N4 & 1.00 & 0.01 & 98 & 47 & 0.99 & 0.11 & 97 & 33 & 1.04 & 0.00 & 100 & 30 & 0.98 & 0.16 & 100 & 25 & 1.24 & 0.39 & 90 & 27 & 1.03 & 0.10100 & 30 \\
\hline N5 & 0.97 & 0.21 & 100 & 47 & 0.82 & 0.26 & 100 & 33 & 0.83 & 0.20 & 100 & 30 & 0.96 & 0.19 & 100 & 25 & 1.32 & 0.36 & 96 & 26 & 1.20 & 0.40100 & 30 \\
\hline N6 & 1.99 & 0.95 & 91 & 43 & 1.10 & 0.53 & 85 & 28 & 1.27 & 0.46 & 90 & 27 & 1.27 & 0.59 & 96 & 24 & 1.20 & 0.25 & 85 & 22 & 1.41 & 0.58100 & 30 \\
\hline $\mathrm{C} 1$ & 7.06 & 3.73 & 65 & 28 & 2.56 & 2.06 & 46 & 13 & 3.30 & 1.71 & 37 & 10 & 2.71 & 1.05 & 58 & 14 & 3.19 & 2.92 & 64 & 14 & 2.41 & $0.80 \quad 97$ & 29 \\
\hline $\mathrm{C} 2$ & 7.32 & 2.94 & 68 & 19 & 3.95 & 2.04 & 77 & 10 & 2.07 & 0.83 & 40 & 4 & 4.51 & 2.87 & 71 & 10 & 4.22 & 2.30 & 79 & 11 & 2.16 & 0.73100 & 29 \\
\hline $\mathrm{C} 3$ & 3.93 & 1.73 & 79 & 15 & 4.33 & 2.55 & 80 & 8 & 2.18 & 1.04 & 100 & 4 & 3.69 & 0.96 & 30 & 3 & 7.51 & 2.90 & 82 & 9 & 1.63 & 0.69100 & 29 \\
\hline $\mathrm{C} 4$ & 6.16 & 3.14 & 87 & 13 & 4.62 & 1.61 & 75 & 6 & 4.06 & 3.22 & 75 & 3 & 2.96 & - & 33 & 1 & 4.91 & 2.47 & 78 & 7 & 1.30 & $0.48 \quad 97$ & 728 \\
\hline C5 M & 5.85 & $5-$ & 100 & 2 & 2.68 & 1.53 & 100 & 3 & - & - & 0 & 0 & - & - & 0 & 0 & 3.96 & $5-$ & 100 & 2 & 1.91 & 0.58100 & 8 \\
\hline $\mathrm{C} 5 \mathrm{~F}$ & 6.02 & 2.60 & 100 & 11 & 4.46 & 1.73 & 100 & 3 & 4.88 & - & 100 & 3 & - & - & 100 & 1 & 5.11 & 1.00 & 100 & 5 & 2.10 & 0.97100 & 20 \\
\hline N1-adult M & 34.77 & - & & 2 & 18.65 & 1.24 & & 3 & - & - & & 0 & - & - & & 0 & 27.02 & $2-$ & & 2 & 15.52 & 1.49 & 8 \\
\hline N1-adult F & 34.06 & 4.32 & & 9 & 28.75 & 5.86 & & 3 & 21.96 & - & & 1 & - & - & & 0 & 30.29 & 0.48 & & 3 & 16.03 & 2.54 & 20 \\
\hline Sex ratio & 5.5 & & & & 1 & & & & - & & & & - & & & & 2.5 & & & & 2.5 & & \\
\hline Survival (Adult) & $23 \%$ & & & & $17 \%$ & & & & $3 \%$ & & & & $0 \%$ & & & & $17 \%$ & & & & $93 \%$ & & \\
\hline
\end{tabular}


stage at the other two higher concentrations. The average post-EDT until adult female was 34.1, 28.8 and 22.0 days at the $10^{3}, 10^{4}$ and $5 \times 10^{4}$ cells $\mathrm{mL}^{-1}$, respectively, and no female survived until the adult stage at $10^{5}$ cells $\mathrm{mL}^{-1}$ (Fig. 1A, Table 2). In Cryptomonas tetrapyrenoidosa diets, the average post-EDT until adult were 27.0 and 15.5 days in males, and 30.1 and 16.0 days in females at $10^{3}$ and $5 \times 10^{4}$ cells $\mathrm{mL}^{-1}$, respectively (Fig. $1 \mathrm{~B}$, Table 2 ). Sex ratios of adults were 5.5 and 1.0 at $10^{3}$ and $10^{4}$ cells $\mathrm{mL}^{-1}$ of C. reinhardtii, respectively, and 2.5 at both food concentrations of C. tetrapyrenoidosa (Table 2).

Throughout all food conditions, pooled naupliar durations varied from 5.13-6.85 days, while copepodid durations were longer and had more variable ranges than naupliar ones (9.51-27.52 days), and the durations for both nauplii and copepodites were significantly different depending on food conditions (Table 3). Although the post hoc Tukey-Kramer test identified the shortest duration of pooled naupliar stages to be at $10^{4}$ cells $\mathrm{mL}^{-1}$ of Chlamydomonas reinhardtii (5.1 days), similar values were also observed for the other food conditions (6-7 days, Table 3). Naupliar stage duration at $10^{3}$ cells $\mathrm{mL}^{-1}$ of Cryptomonas tetrapyrenoidosa was ca. 2 days longer than the short- est duration (Table 3) even at the same carbon concentration (see Table 1). For each naupliar stage, post hoc tests showed that the stage durations were not so significantly different between each of the various food conditions, although Kruskal-Wallis tests showed significant differences between all food conditions for every stage (Table 2, S1). The pooled copepodid durations varied greatly under different food conditions, with the shortest value (9.51) being recorded at $5 \times 10^{4}$ cells $\mathrm{mL}^{-1}$ of C. tetrapyrenoidosa (Table 3). The combined copepodid stage duration was also the shortest under this food condition (Table 2, S1).

Regression analyses between the post-EDT until adult and natural log-transformed carbon concentration $(F C$, $\mathrm{mgC} \mathrm{L}^{-1}$ ) for each food condition were made (Fig. 2). The post-EDT ( $D T$, days) linearly decreased with increasing $\ln F C$ for both males and females, and the equations were:

$$
\begin{aligned}
& D T=-2.813 \ln F C+22.813 \\
& \quad\left(n=15, r^{2}=0.733, t=3.488, p<0.05\right) \text { for males, and } \\
& D T=-2.997 \ln F C+25.644 \\
& \quad\left(n=36, r^{2}=0.953, t=5.732, p<0.05\right) \text { for females. }
\end{aligned}
$$

ANCOVA showed no significant difference of the post-
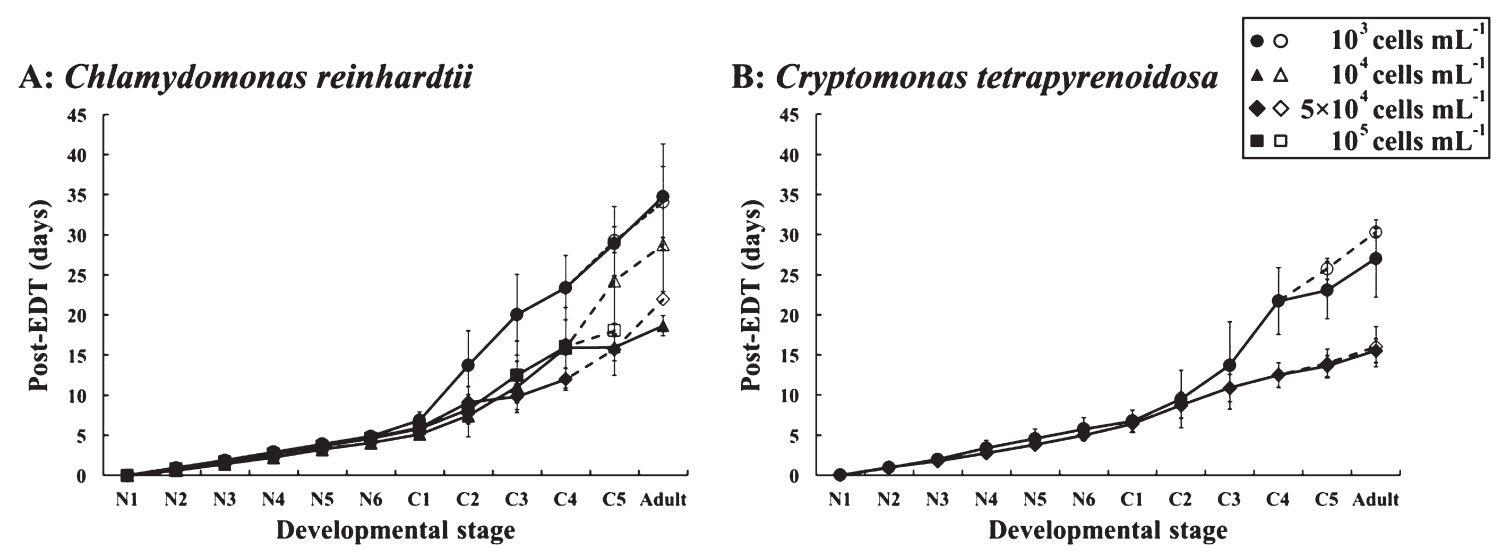

Fig. 1. Post-embryonic development time (post-EDT, days) of developmental stages from N1 to adult in Mongolodiaptomus malaindosinensis in males (solid symbols and solid lines) and females (open symbols and dotted lines) reared at food concentrations of $10^{3}$ (circles), $10^{4}$ (triangles), $5 \times 10^{4}$ (diamonds) and $10^{5}$ (squares) cells $\mathrm{mL}^{-1}$ of Chlamydomonas reinhardtii (A) and $10^{3}$ (circles) and $5 \times 10^{4}$ (diamonds) cells $\mathrm{mL}^{-1}$ of Cryptomonas tetrapyrenoidosa (B) at $25^{\circ} \mathrm{C}$. Vertical bars represent standard deviations.

Table 3. Pooled stage durations (days) of naupliar and copepodid stages at different concentrations of Chlamydomonas reinhardtii and Cryptomonas tetrapyrenoidosa diets. The durations were the average of the duration from $\mathrm{C} 1$ to Adult for all individuals, regardless of whether male or female, and was not the simple sum of each stage duration in Table 2. Statistical analyses on stage durations showed differ-

\begin{tabular}{|c|c|c|c|c|c|c|c|c|c|}
\hline \multirow{2}{*}{ Stage } & \multicolumn{4}{|c|}{ C. reinhardtii (cells $\mathrm{mL}^{-1}$ ) } & \multicolumn{2}{|c|}{$\begin{array}{l}\text { C. tetrapyrenoidosa } \\
\left(\text { cells } \mathrm{mL}^{-1}\right)\end{array}$} & \multicolumn{3}{|c|}{ Kruskal-Wallis test } \\
\hline & $10^{3}$ & $10^{4}$ & $5 \times 10^{4}$ & $10^{5}$ & $10^{3}$ & $5 \times 10^{4}$ & $d f$ & $\chi^{2}$ & $P$ value \\
\hline Naupliar & $6.85^{\mathrm{a}}$ & 5.13 & $5.94^{\mathrm{b}}$ & $5.82^{\mathrm{b}}$ & $6.77^{\mathrm{a}, \mathrm{b}}$ & $6.39^{\mathrm{a}, \mathrm{b}}$ & 5,168 & 47.09 & $<0.001$ \\
\hline Copepodid & $27.52^{\mathrm{a}}$ & $18.67^{\mathrm{a}}$ & $16.71^{*}$ & —* & $23.28^{\mathrm{a}}$ & 9.51 & 3,47 & 37.47 & $<0.001$ \\
\hline
\end{tabular}
ences among the six food conditions. Hyphen represents no data. Values with the same superscript characters in each tested stage indicate no significant difference among food conditions (post-hoc Tukey-Kramer test, $d f=168$ and 47 in naupliar and copepodid stages, respectively, $p>0.05$ for both). ${ }^{*}$ ) No statistical tests were done due to the small data size (see Table 2 ). 


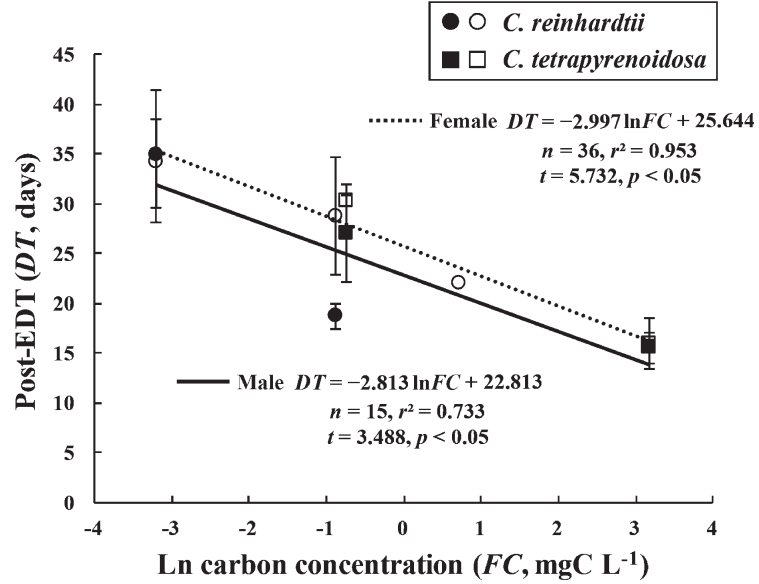

Fig. 2. Relationship between post-embryonic development times (post-EDTs, days) of adult Mongolodiaptomus malaindosinensis and food concentration at $25^{\circ} \mathrm{C}$. Solid and open symbols represent males and females, respectively. Six food conditions were transformed to natural logarithms of carbon concentrations $\left(F C, \mathrm{mgC} \mathrm{L}^{-1}\right)$. Circles and squares represent Chlamydomonas reinhardtii and Cryptomonas tetrapyrenoidosa, respectively. Regression equations and coefficients of determination are indicated for males (solid line) and females (dotted line).

EDT between adult male and female $(d f=1,48, F=3.59$, $p=0.064$ ). Although the mean value at $10^{4}$ cells $\mathrm{mL}^{-1}$ of Chlamydomonas reinhardtii was below the regression line, ANOVA showed no significant difference of the postEDT between the two algal diets at a carbon supply of $0.4-0.5 \mathrm{mgC} \mathrm{L}^{-1}(d f=1,9, F=2.62, p=0.140)$.

\section{Survival rate}

The highest survival rate to reach the adult stage was $93 \%$ and was observed at the highest concentration of Cryptomonas tetrapyrenoidosa, whereas either no or quite few (3\%) adults survived even at the highest and next highest cell concentrations of Chlamydomonas reinhardtii, respectively (Table 2). In all remaining treatments, 17-23\% survived regardless of food concentration or type. During the naupliar stages, at least $73 \%$ of the experimental animals survived regardless of the food conditions, but more than half of the animals that molted to the 1st copepodid stage died before adulthood under any food condition, except for at the highest concentration of $C$. tetrapyrenoidosa (Table 2). The Kruskal-Wallis test showed that pooled stage specific survival rates from $\mathrm{C} 1$ to $\mathrm{C} 4$ were significantly different between the food conditions $(d f=4$, 13, $\left.x^{2}=10.14, p=0.038\right)$. The post-hoc test indicated that specific survival rates were highest at $5 \times 10^{4}$ cells $\mathrm{mL}^{-1}$ of $C$. tetrapyrenoidosa and not significantly different between those under any of the remaining conditions (Fig. 3).

\section{Body size}

Under Chlamydomonas reinhardtii diets, mean adult

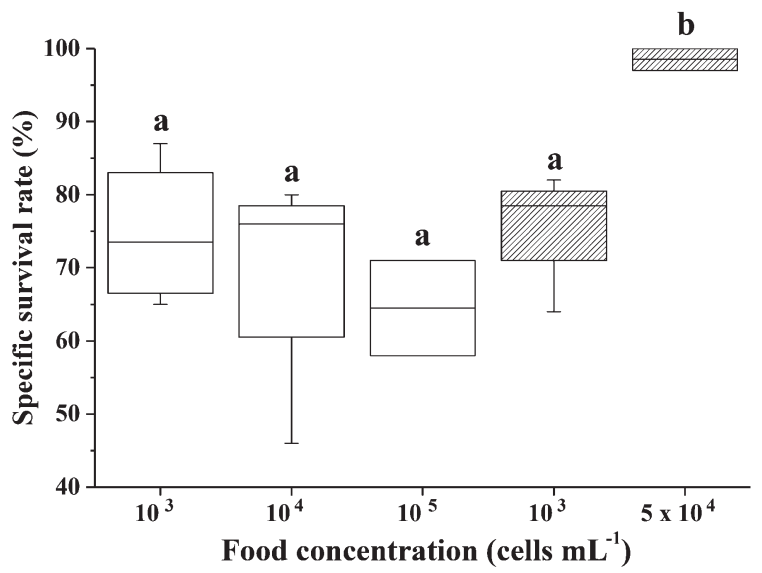

Fig. 3. Box plots of stage specific survival rates (\%) of 1 st to fourth copepodid stages at each different food concentration (cells $\mathrm{mL}^{-1}$ ) of the two algal diets. Open and shaded boxes represent Chlamydomonas reinhardtii and Cryptomonas tetrapyrenoidosa, respectively. Horizontal line represents the median value. The same alphabetical characters above boxes indicate no significant difference among food conditions (the post hoc Tukey-Kramer test, $d f=13, p>0.05)$.

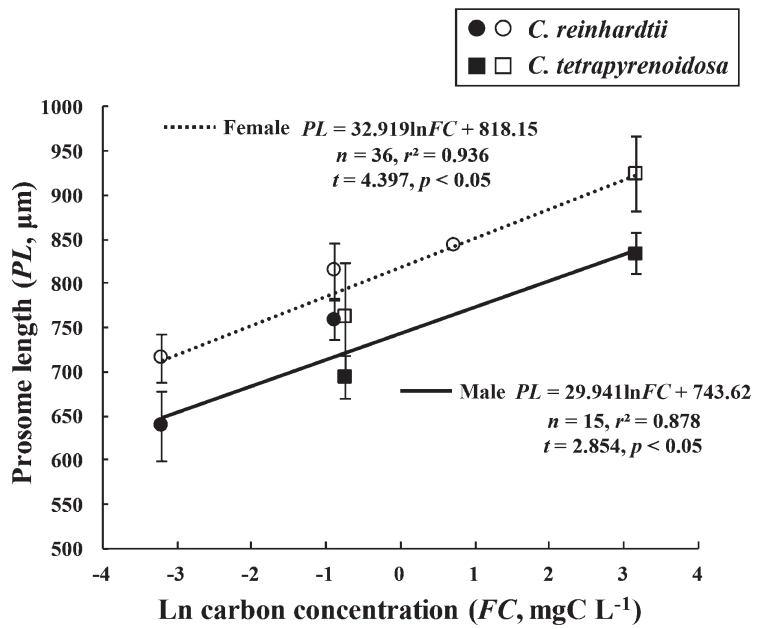

Fig. 4. Relationship between prosome lengths $(P L, \mu \mathrm{m})$ of adult Mongolodiaptomus malaindosinensis and food concentrations at $25^{\circ} \mathrm{C}$. Solid and open symbols represent males and females, respectively. Six food conditions were transformed to natural logarithms of carbon concentrations $\left(F C, \mathrm{mgC} \mathrm{L}^{-1}\right)$. Circles and squares represent Chlamydomonas reinhardtii and Cryptomonas tetrapyrenoidosa, respectively. Regression equations and coefficients of determination are indicated for males (solid line) and females (dotted line).

PLs were 638 and $759 \mu \mathrm{m}$ in males at $10^{3}$ and $10^{4}$ cells $\mathrm{mL}^{-1}$, respectively, whereas they were 715,814 and $844 \mu \mathrm{m}$ in females at $10^{3}, 10^{4}$ and $5 \times 10^{4}$ cells $\mathrm{mL}^{-1}$ (Fig. 4). Under Cryptomonas tetrapyrenoidosa diets, the mean adult $P L \mathrm{~s}$ were 694 and $834 \mu \mathrm{m}$ in males, and 762 and $924 \mu \mathrm{m}$ in females at $10^{3}$ and $5 \times 10^{4}$ cells $\mathrm{mL}^{-1}$, respectively (Fig. 4). Regression analyses showed that the $P L$ 
of adults linearly increased with increasing $\ln F C$ in both males and females (Fig. 4) and the equations were:

$$
\begin{aligned}
P L= & 29.941 \ln F C+743.62 \\
& \left(n=15, r^{2}=0.878, t=2.854, p<0.05\right) \text { for males, and } \\
P L= & 32.919 \ln F C+818.15 \\
& \left(n=36, r^{2}=0.936, t=4.397, p<0.05\right) \text { for females. }
\end{aligned}
$$

ANCOVA found significant differences in PL between males and females $(d f=1,48, F=42.92, p<0.001)$. ANOVA found no significant differences in adult $P L$ between the two algal diets at a carbon supply of $0.4-0.5 \mathrm{mgC} \mathrm{L}^{-1}$ $(d f=1,9, F=3.03, p=0.116)$. Larval development during copepodid stages are shown in Fig. 5. At all food conditions, log-transformed body dry-weight linearly increased with increasing development times. The slopes, i.e. the instantaneous growth rates $\left(g\right.$, day $\left.^{-1}\right)$, increased from 0.08 to 0.32 day $^{-1}$ when food carbon concentration $(F C)$ increased from the lowest $(0.04)$ to the highest $\left(23.68 \mathrm{mgC} \mathrm{L}^{-1}\right)$ value (Fig. 5, Table 1). The relationship between $g$ and log-transformed $F C$ fitted well to the exponential equation $\left(r^{2}=0.889\right)$, being accelerated above $4.0 \mathrm{mgC} \mathrm{L}^{-1}$ (Fig. 5).

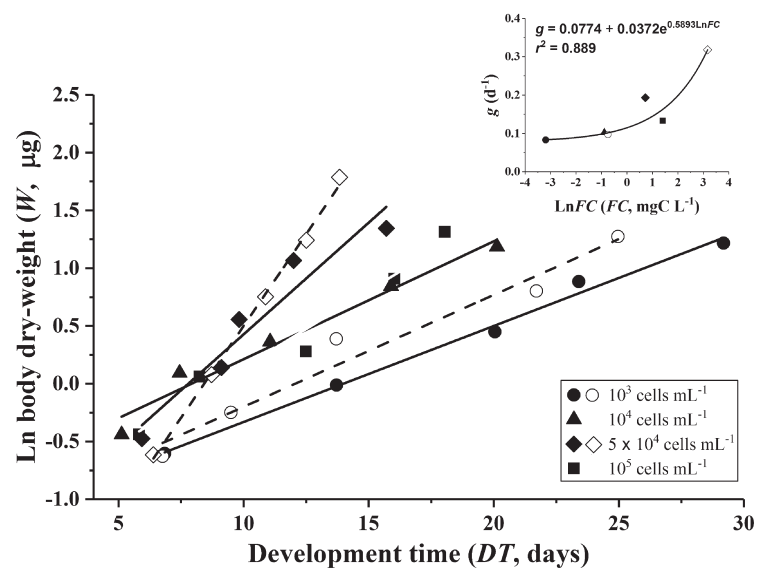

Fig. 5. Relationships between log-transformed body dryweight $(W, \mu \mathrm{g})$ and post-embryonic development times $(D T$, days) during copepodite stages $\mathrm{C} 1$ to $\mathrm{C} 5$ in Mongolodiaptomus malaindosinensis at different food concentrations (circles, triangles, diamonds and squares are cell concentrations of $10^{3}$, $10^{4}, 5 \times 10^{4}$ and $10^{5}$ cells $\mathrm{mL}^{-1}$, respectively) of Chlamydomonas reinhardtii (solid symbols and solid lines) and Cryptomonas tetrapyrenoidosa (open symbols and dashed lines). The regression lines were expressed as: $\operatorname{Ln} W=0.0831 D T-1.1623\left(r^{2}=0.993\right)$, $\operatorname{Ln} W=0.102 D T-0.8082 \quad\left(r^{2}=0.969\right), \quad \operatorname{Ln} W=0.1933 D T-1.5066$ $\left(r^{2}=0.928\right), \mathrm{Ln} W=0.1326 D T-1.1847\left(r^{2}=0.962\right)$ at $10^{3}, 10^{4}, 5 \times 10^{4}$ and $10^{5}$ cells $\mathrm{mL}^{-1}$ of $C$. reinhardtii, and $\mathrm{Ln} W=0.0968 D T-1.1679$, $\left(r^{2}=0.965\right), \operatorname{Ln} W=0.3177 D T-2.6772,\left(r^{2}=0.997\right)$ at $10^{3}$ and $5 \times 10^{4}$ cells $\mathrm{mL}^{-1}$ of $C$. tetrapyrenoidosa, respectively. The inset presents the relationship between instantaneous growth rate $\left(g\right.$, day $\left.{ }^{-1}\right)$ and natural $\log$-transformed food carbon concentration $\left(F C, \mathrm{mgC} \mathrm{L}^{-1}\right)$ fitted with an exponential equation (solid line, $g=0.0774+0.0372$ $\left.\mathrm{e}^{0.5893 \operatorname{Ln} F C}, r^{2}=0.889\right)$.

\section{Discussion}

In this study, post-EDTs of the tropical copepod Mongolodiaptomus malaindosinensis decreased with increasing food concentrations for both algal diets, suggesting that development time of this copepod was strongly correlated with food quantity. This response has been reported for many other copepod species, e.g., tropical species of Arctodiaptomus dorsalis in Lake Taal, Philippines (Tordesillas et al. 2016), temperate species of Eurytemora affinis Poppe, 1880 in Lake Ohnuma, Japan (Ban 1994), Eodiaptomus japonicus Burckhardt, 1913 in Lake Biwa, Japan (Liu et al. 2015), the arctic species Calanus glacialis Jaschnov, 1955 in the Arctic Ocean (Søreide et al. 2010) and Pseudocalanus elongatus Boeck, 1865 in the southern North Sea (Renz et al. 2008). According to this, development times of copepod species distributed over wide ranges of latitudes from tropical to boreal regions were all sensitive to food quantity.

Sex ratios in copepods can be related to adaptability of populations to environmental factors (Dussart \& Defaye 2001). For example, in Eurytemora affinis collected from an estuary, the proportions of males were always higher than females at all tested temperatures and salinity levels, but showed a slightly higher proportion of females at lower temperatures (Devreker et al. 2007). In Eodiaptomus japonicus, the sex ratios increased with decreasing food supply at $15^{\circ} \mathrm{C}$ but the results showed no clear relationship between sex ratio and food supply at $25^{\circ} \mathrm{C}$ (Liu et al. 2015). The tropical copepod Arctodiaptomus dorsalis exhibited the highest sex ratio of 3.0 at the lowest temperature over the total tested temperature range of $25-35^{\circ} \mathrm{C}$ (Tordesillas et al. 2016). In this study, the highest sex ratio of 5.5 in Mongolodiaptomus malaindosinensis was observed at the lowest carbon supply level. The sex ratios seem to be skewed to females when copepods were under challenging conditions for growth, such as low temperatures and/ or food shortages. It is known that efficient location of a mating partner and multiple mating over the course of their reproductive period in copepods makes them successful in the pelagic region (Kiørboe 2011), and that calanoid females often carry several spermatophores, reflecting multiple mating events (Dussart \& Defaye 2001). A sex ratio skewed to females under food-limited conditions might be in order to avoid population extinction through enhancing the possibility of mating and because a high proportion of females can produce more offspring simultaneously.

Copepods in early naupliar stages cannot feed until the development of their oral aperture is complete and until then they live on yolk reserves (Dussart \& Defaye 2001). For example, Eurytemora affinis starts feeding at N2 (Ban 1994), Tortanus discaudatus (Thompson \& Scott, 1897) (Ambler \& Frost 1974), Eucalanus pileatus Giesbrecht, 1888 and Eucalanus crassus Giesbrecht, 1888 (Paffenhöfer \& Lewis 1989) at N4. It has been reported that food shortage does not influence yolk investment in copepod eggs 
(Jamieson 1986), and that the durations of non-feeding stages can be affected by temperature regardless of food supply rates (Liu et al. 2015) due to temperature-mediated metabolic rates (Brown et al. 2004, Liu \& Ban 2017). In this study, the N1 duration in M. malaindosinensis was shortest regardless of food conditions due to the N1 stage being non-feeding, as confirmed by observations of empty guts and the fact that many lipids were found inside the N1 bodies.

In the present study, Mongolodiaptomus malaindosinensis exhibited the shortest naupliar stage duration of ca. 5.1 days at $10^{4}$ cells $\mathrm{mL}^{-1}$ under the smaller cell size and potentially lower quality diet of Chlamydomonas reinhardtii. This food concentration was equivalent to $0.41 \mathrm{mgC} \mathrm{L}^{-1}$ and was similar to that of $10^{3}$ cells $\mathrm{mL}^{-1}$ in the larger and potentially better diet of Cryptomonas tetrapyrenoidosa, under which the naupliar stage duration of M. malaindosinensis was ca. 2 days longer than that in the former (6.8 days). These results suggest that M. malaindosinensis seems to prefer smaller-size phytoplankton during the naupliar stages because of insufficient development of the feeding apendages in the larval stages (Mauchline 1998). However, the similar duration and survival rate during naupliar stages, even at the lowest concentration in C. reinhardtii, being equivalent to the lowest carbon concentration of $0.04 \mathrm{mgC} \mathrm{L}^{-1}$, suggests that the lowest carbon supply condition used in this study was sufficient for naupliar development in M. malaindosinensis.

Both the post-EDT and adult body size in Mongolodiaptomus malaindosinensis were only correlated with carbon supply, regardless of the algal species used. The highest instantaneous growth rate $(g)$ of 0.32 day $^{-1}$ in this copepod was observed at the highest carbon concentration of $23.7 \mathrm{mgC} \mathrm{L}^{-1}$. Therefore, limitations on growth in the field might occur when food quantities are at levels lower than this carbon concentration. Temperate species have been reported to have lower somatic growth rates than this, for example, the highest instantaneous growth rate $(g)$ was ca. 0.29 day $^{-1}$ in Eodiaptomus japonicus reared at $25^{\circ} \mathrm{C}$ under ad libitum food conditions of ca. $13 \mathrm{mgC} \mathrm{L}^{-1}$ (Liu et al. 2015). According to the temperature-growth equation provided in Lee et al. (2003), the estimated instantaneous somatic growth rate at $25^{\circ} \mathrm{C}$ was $0.28 \mathrm{day}^{-1}$ in Pseudocalanus newmani Frost, 1989 under a carbon supply rate of just $0.36 \mathrm{mgC} \mathrm{L}^{-1}$, which was nearly the same as the maximum phytoplankton biomass in situ (Ban et al. 2000). In Acartia tonsa Dana, 1849, metabolic rate did not increase when carbon supply exceeded $1 \mathrm{mgC} \mathrm{L}^{-1}$ (Kiørboe et al. 1985). According to these comparisons, M. malaindosinensis may exhibit a higher upper-threshold for the effect of carbon supply on somatic growth than in these temperate species. Weight-specific metabolic costs in copepods always have been reported to be higher in tropical species than in temperate ones (Beyrend-Dur 2010). This copepod might be considered a trophic specialist, being adapted to high temperatures and large amounts of food resources, because natural ponds in tropical regions have greater amounts of food resources (Schalk et al. 2017).

In copepods, females generally require a longer development time than males (Lee et al. 2003, Liu \& Ban 2018) due to the long duration of $C 5$ in females caused by maturation of oocytes in the oviducts (Peterson 1986, Ban 1994). Parallel maturation among copepod genders might take advantage of producing offspring immediately after their moulting to adults, consequently contributing to their population growth. However, parallel maturation depends on environmental conditions. For example, in the estuarine copepod Eurytemora affinis, females were reported to reach the adult stage at the same time as males did at $15^{\circ} \mathrm{C}$ and a salinity of 25 , while the females needed longer times than males, especially for $\mathrm{C} 5$, at $10^{\circ} \mathrm{C}$, regardless of salinity (Devreker et al. 2007). In this study, ANCOVA suggested the post-EDTs of Mongolodiaptomus malaindosinensis were not significantly different between males and females, although the development times were significantly shorter in males than in females at $10^{4}$ cells $\mathrm{mL}^{-1}$ in Chlamydomonas reinhardtii, with large individual variation. More data are required to determine the difference in post-EDT among $M$. malaindosinensis genders.

In temperate copepods, e.g. Eurytemora affinis (Ban 1994), Pseudocalanus newmani (Lee et al. 2003) and Eodiaptomus japonicus (Liu et al. 2015), they mainly died during the naupliar stages, but usually matured to adults regardless of temperature and food conditions after they had successfully moulted from the naupliar to copepodid stages. On the contrary, tropical species showed different features related to survival, for example where dramatically increased mortality was always observed during the copepodid stages in Arctodiaptomus dorsalis from Lake Taal in the Philippines (Tordesillas et al. 2016). In the present study, Mongolodiaptomus malaindosinensis mostly survived during the naupliar stages, but fewer individuals survived during the copepodid stages, especially $\mathrm{Cl}$, which is a transitional stage with large morphological changes, at food carbon concentrations lower than $23.7 \mathrm{mgC} \mathrm{L}^{-1}$. It has been shown that low survival during the copepodid stages is due to the large morphological and physiological changes from N6 to $\mathrm{C} 1$ and higher energy consumption than during the naupliar stages (Epp \& Lewis 1980). Food conditions may play a crucial role during the copepodid stages, especially in tropical copepods, due to high metabolic costs at high temperatures (Brown et al. 2004, Liu \& Ban 2017).

Both somatic growth and survival of Mongolodiaptomus malaindosinensis were influenced by food quantity regardless of the algal species used, although Chlamydomonas reinhardtii has been reported to not be suitable food for temperate copepod species in previous studies (Celia \& Folt 1993, Hart \& Santer 1994). Chemical compositions of different algal species play an important role in regulating copepod somatic growth (Brown et al. 2004, Dahl et al. 2009). Food resources for copepods may differ in different 
habitats and result in different responses to food availability. Natural ponds in tropical regions have a greater variety of algal species and ranges in the amounts of food resources for copepods than in temperate regions. Tropical copepods may be adapted to greater food quantities due to higher water temperatures and more varieties of food algae than temperate copepods. These results suggest that tropical copepods need more energy for their growth due to higher metabolic costs under higher temperatures but that they are adapted to variable food resources.

\section{Acknowledgements}

This research was supported by the Thai Government's Program Strategic Scholarships for Frontier Research Network for AJ's Ph.D. fellowship, under the National Science and Technology Development Agency (NSTDA) and Applied Taxonomic Research Center, Khon Kaen University, Thailand. We express thanks to Dr. D. T. Tordesillas for his kind help in the maintenance of copepod culture during the experiments and also for constructive advice and comments on this study.

\section{References}

Almeida L, Costa I, Eskinazi-Sant'AE (2012) Composition and abundance of zooplankton community of an impacted estuarine lagoon in Northeast Brazil. Braz J Biol 72: 12-24.

Ambler JW, Frost BW (1974) The feeding behavior of a predatory copepod, Tortanus discaudatus. Limnol Oceanogr 19: 446-451.

Ban S (1994) Effect of temperature and food concentration on post-embryonic development, egg production and adult body size of calanoid copepod Eurytemora affinis. J Plankton Res 16: 721-735.

Ban S, Lee HW, Shinada A, Toda T (2000) In situ egg production and hatching success of the marine copepod Pseudocalanus newmani in Funka Bay and adjacent waters off southwestern Hokkaido, Japan: associated to diatom bloom. J Plankton Res 22: 907-922.

Beyrend-Dur D (2010) Life history traits of key brackish copepods from temperate to tropical environments. University of Lille, France/National Taiwan Ocean University, Taiwan, pp. 1-216.

Brown JH, Gillooly JF, Allen AP, Savage VM, West GB (2004) Toward a metabolic theory of ecology. Ecology 85: 1771-1789.

Burns CW (1998) Life history consequences of food quality in the freshwater copepod Boeckella triarticulata. Ecology 79: 1711-1724

Celia YC, Folt CL (1993) Measures of food quality as demographic predictors in freshwater copepods. J Plankton Res 15: 1247-1261.

Chisholm LA, Roff JC (1990) Size-weight relationships and biomass of tropical neritic copepods off Kingston, Jamaica. Mar Biol 106: 71-77.

Dahl U, Lind CR, Gorokhova E, Eklund B, Breitholtz M (2009) Food quality effects on copepod growth and development: im- plications for bioassays in ecotoxicological testing. Ecotox Environ Safe 72: 351-357.

DeMott WR (1986) The role of taste in food selection by freshwater zooplankton. Oecologia 63: 334-340.

DeMott WR (1989) Optimal foraging theory as a predictor of chemically mediated food selection by suspension-feeding copepods. Limnol Oceanogr 34: 140-154.

Devreker D, Souissi S, Forget-Leray J, Leboulenger F (2007) Effects of salinity and temperature on the post-embryonic development of Eurytemora affinis (Copepoda; Calanoida) from the Seine estuary: a laboratory study. J Plankton Res 29: 117-133.

Dussart BH, Defaye D (2001) Introduction to the Copepoda. In: Guides to the Identification of the Microinvertebrates of the Continental Waters of the World (ed Dumont, HJ). Backhuys, Leiden, The Netherlands, pp. 1-344.

Epp RW, Lewis WM (1980). The nature and ecological significance of metabolic changes during the life history of copepods. Ecology 61: 259-264.

Hansen A-M, Santer B (1995) The influence of food resources on the development, survival and reproduction of the two cyclopoid copepods: Cyclops vicinus and Mesocyclops leuckarti. J Plankton Res 17: 631-646.

Hart RC (1996) Naupliar and copepodite growth and survival of two freshwater calanoids at various food levels: Demographic contrasts, similarities, and food needs. Limnol Oceanogr 41: 648-658.

Hart RC, Santer B (1994) Nutritional suitability of some unialgal diets for freshwater calanoids: unexpected inadequacies of commonly used edible greens and others. Freshwater Biol 31: 109-116.

Hsieh CH, Ishikawa K, Saka, Y, Ishikawa T, Ichise S, Yamamoto Y, Kuo TC, Park HD, Yamamura N, Kumagai M (2010) Phytoplankton community reorganization driven by eutrophication and warming in Lake Biwa. Aquat Sci 72: 467-483.

Hsieh CH, Sakai Y, Ban S, Ishikawa K, Ishikawa T, Ichise S (2011) Eutrophication and warming effects on long-term variation of zooplankton in Lake Biwa. Bio-Geosci Discuss 8: 593-629.

IBM Inc (2011) IBM SPSS Statistics (predictive analytics software and solutions). Version 19.0.

Jamieson, CD (1986) The effects of temperature and food on naupliar development, growth and metamorphosis in three species of Boeckella (Copepoda: Calanoida). Hydrobiologia 139: $277-286$.

Kiørboe T (2011) What makes pelagic copepods so successful? J Plankton Res 33: 677-685.

Kiørboe T (2016) Fluid dynamic constraints on resource acquisition in small pelagic organisms. Eur Phys J Special Topics 225: 669-683.

Kiørboe T, Møhlenberg F, Hamburger K (1985) Bioenergetics of the planktonic copepod Acartia tonsa: relation between feeding, egg production and respiration, and composition of specific dynamic action. Mar Ecol Prog Ser 26: 85-97.

Kottelat M (2007) A freshwater diaptomid copepod harvested for human consumption in central Laos. Raffles Bull Zool Suppl No. 16: 355-357.

Koski M, Breteler WK (2003) Influence of diet on copepod survival in the laboratory. Mar Ecol Prog Ser 264: 73-82. 
Lai HC, Fernando CH (1978) Redescription of Neodiaptomus botulifer Kiefer and one of its related species (Calanoida, Copepoda). Hydrobiologia 59: 229-235.

Lee H, Ban S, Ikeda T, Matsuishi T (2003) Effect of temperature on development growth and reproduction in the marine copepod Pseudocalanus newmani at satiating food condition. J Plankton Res 25: 261-271.

Liu X, Ban S (2017) Effects of acclimatization on metabolic plasticity of Eodiaptomus japonicus (Copepoda: Calanoida) determined using an optical oxygen meter. J Plankton Res 39: $111-121$.

Liu X, Ban S (2018) Effects of temperature and nutritional conditions on physiological responses of the freshwater copepod Eodiaptomus japonicus in Lake Biwa, (Japan). Limnol Stud 5: $13-24$.

Liu X, Beyrend-Dur D, Dur G, Ban S (2014) Effects of temperature on life history traits of Eodiaptomus japonicus (Copepoda: Calanoida) from Lake Biwa (Japan). Limnology 15: 85-97.

Liu X, Beyrend D, Dur G, Ban S (2015) Combined effects of temperature and food concentration on growth and reproduction of Eodiaptomus japonicus (Copepoda: Calanoida) from Lake Biwa (Japan). Freshwater Biol 60: 2003-2018.

Mauchline J (1998) The Biology of Calanoid Copepods. In: Advances in Marine Biology (eds Blaxter JHS, Southward AJ, Tyler PA). Academic Press, Great Britain, pp. 1-710.

McKinnon AD (1996) Growth and development in the subtropical copepod Acrocalanus gibber. Limnol Oceanogr 41: 14381447.

Paffenhöfer G, Lewis K (1989) Feeding behavior of nauplii of the genus Eucalanus (Copepoda, Calanoida). Mar Ecol Prog Ser 57: 129-136.

Peterson WT (1986) Development, growth, and survivorship of the copepod Calanus marshallae in the laboratory. Mar Ecol Prog Ser 29: 61-72.

Peterson WT, Tiselius P, Kiørboe T (1991) Copepod egg-production, molting and growth-rates, and secondary production, in the Skagerrak in August 1988. J Plankton Res 13: 131-154.

Piasecki W, Goodwin AE, Eiras JC, Nowak, BF (2004) Importance of Copepoda in freshwater aquaculture. Zool Stud 43: 193-205.

Proongkiat I, Sanoamuang L (2008) Description of Neodiaptomus siamensis, a new diaptomid copepod (Copepoda, Calanoida) from temporary pools in northern Thailand. Crustaceana 81: 177-189.

Ranga Reddy Y, Sanoamuang L, Dumont HJ (1997) A note on the Diaptomidae of Thailand, including redescription of three species and description of a new species (Copepoda, Calanoida). Hydrobiologia 361: 201-223.

Ranga Reddy Y, Sanoamuang L, Dumont HJ (2000) Amended delimitation of Mongolodiaptomus against Neodiaptomus and Allodiaptomus and redescription of the little known Mongolodiaptomus uenoi (Kikuchi, 1936) from Thailand (Copepoda: Calanoida: Diaptomidae). Hydrobiologia 418: 99-109.

Renz J, Mengedoht D, Hirche HJ (2008) Reproduction, growth and secondary production of Pseudocalanus elongatus Boeck (Copepoda, Calanoida) in the southern North Sea. J Plankton Res 30: 511-528.

Royal Irrigation Department (2016) Water management and ag- riculture in irrigating area. Office of Water Management and Hydrology, Ministry of Agriculture and Cooperatives, Thailand, pp. 1-90.

Sanoamuang L (1999) Species composition and distribution of freshwater Calanoida and Cyclopoida (Copepoda) of northeast Thailand. In: Crustaceans and Biodiversity Crisis (eds Schram FR, Klein JCV). Brill Academic Publishers, Leiden, The Netherlands, vol. I: 217-230.

Sanoamuang L (2001) Mongolodiaptomus dumonti n. sp., a new freshwater copepod (Calanoida, diaptomidae) from Thailand. Hydrobiologia 448: 41-52.

Sanoamuang L (2002) Freshwater Zooplankton: Calanoid Copepods in Thailand. Klang Nana Publishing, Khon Kaen, Thailand, pp. 1-159.

Sanoamuang L (2004) Heliodiaptomus phuthaiorum n. sp., a new freshwater copepod (Calanoida, Diaptomidae) from temporary ponds in northeast Thailand. Int Rev Hydrobiol 89: 392-406.

Sanoamuang L, Teeramaethee J (2006) Phyllodiaptomus thailandicus, a new freshwater copepod (Copepoda, Calanoida, Diaptomidae) from Thailand. Crustaceana 79: 475-487.

Santhanam P, Jothiraj K, Jeyaraj N, Jeyanthi S, Devi AS, Ananth $S$ (2015) Effect of monoalgal diet on the growth, survival and egg production in Nannocalanus minor (Copepoda: Calanoida). Indian J Geo-Mar Sci 44: 1579-1584.

Schalk CM, Montaña CG, Winemiller KO, Fitzgerald LA (2017) Trophic plasticity, environmental gradients and food-web structure of tropical pond communities. Freshwater Biol 62: 519-529.

Søreide JE, Leu E, Berge J, Graeve M, Falk-Petersen S (2010) Timing of blooms, algal food quality and Calanus glacialis reproduction and growth in a changing Arctic. Global Change Biol 16: 3154-3163.

The MathWorks Inc (2009) MATLAB (the language of technical computing). Version 7.8.0.347 (R2009a).

Tordesillas D, Paredes P, Villarue, K, Queneri C, Rico J, Ban S, Papa R (2018) Effects of food concentration on the reproductive capacity of the invasive freshwater calanoid copepod Arctodiaptomus dorsalis (Marsh, 1907) in the Philippines. J Crustacean Biol 38: 101-106.

Tordesillas DT, Abaya NKP, Dayo MAS, Marquez LEB, Papa RDS, Ban S (2016) Effect of temperature on life history traits of the invasive calanoid copepod Arctodiaptomus dorsalis (Marsh, 1907) from Lake Taal, Philippines. Plankton Benthos Res 11: 105-111.

Twombly S, Burns CW (1996) Effects of food quality on individual growth and development in the freshwater copepod Boeckella triarticulata. J Plankton Res 18: 2179-2196.

Watiroyram S, Sanoamuang L (2017) A new species of Mongolodiaptomus Kiefer, 1938 from Northeast Thailand and a key to the species (Crustacea, Copepoda, Calanoida, Diaptomidae). Zookeys 710: 15-32.

Williamson CE, Reid JW (2001) Copepoda. In: Ecology and Classification of North American Freshwater Invertebrates (eds Thorp JH, Covich AP), Academic Press, New York, pp. 915-954.

Wu RSS (1999) Eutrophication, water borne pathogens and xenobiotic compounds: environmental risks and challenges. Mar Pollut Bull 39: 11-22. 